\title{
Making the Umwelt Bubble of the Modern Synthesis Burst
}

\section{Morten Tønnessen ${ }^{1}$}

Received: 3 March 2021 / Accepted: 21 April 2021 / Published online: 9 May 2021

(C) The Author(s) 2021

\begin{abstract}
Noble rightly emphasizes that some modern evolutionary biologists' neglect of agency is consequential with regard to our understanding of the natural world and real-world ecological developments. I elaborate on biosemiotic ideas on semiotic agency and explain how organisms can change the environment by way of semiotic causation. I also comment on the human language's role in human Umwelten, and how our linguistically mediated reality can be self-deceptive - as if we lived in a bubble of our own making. Finally, I indicate how we can make the Umwelt bubble of the Modern Synthesis burst.
\end{abstract}

Keywords Semiotic agency $\cdot$ Semiotic causation · Anthropocene $\cdot$ Umwelt theory $\cdot$ Naivety of prey · Language

\section{Background}

In this commentary, I comment and elaborate on some of Denis Noble's observations, particularly those that draw on my work, but also his important observation about the danger of neglecting agency in humans and non-humans.

\section{Agency and Environment}

In a general understanding, “"agency' denotes the exercise or manifestation of" "an agent['s] capacity to act" (Schlosser, 2019). In a biosemiotic understanding, agency is semiotic in nature, and related to an agent's capacity for making choices while relating to signs. Noble emphasizes some modern evolutionary biologists' neglect of agency. This is a crucial point. In his view (2021), the evolution of "[c]onsciousness and the

Morten Tønnessen

morten.tonnessen@uis.no

1 University of Stavanger, Nådlandsbråtet 25, 4034 Stavanger, Norway 
neural structures that support it and the capacity to make intentional choices [...] required payback in terms of selective advantages", which he believes "the nervous system has given us". Noble (2021) then suggests that the emergence of such capacities "may even have been one of the drivers of the Cambrian Explosion", which would imply that "one of the most important transitions in evolution was actually driven by organism agency, not by natural selection." From a biosemiotic point of view (reviewed in Tønnessen, 2015a), not only are all conscious organisms endowed with semiotic agency - any organism is.

Noble distinguishes between intended selection, carried out by organisms (e.g. in mate selection, or humans' domestication of animals), and natural selection, which is unintended. The implication is that both are actual factors in evolution; only the former, however, is related to genuine agency - and its existence is denied by The Modern Synthesis. Elsewhere, Noble (2015: 10) has noted that a shortcoming of a NeoDarwinist understanding of evolution is "the misconception that all the active causal determination lies in the one-dimensional DNA sequences". This ignores the role played by organismal form and cell structure. In evolutionary history, "the basic features of structural organisation" must have appeared "before the relevant genomic information was developed" (2015: 10). Such phenotypic elements of construction cannot have been caused by natural selection. As Müller and Newman (2003: 3) remark, "selection can only work on what already exists." In this understanding, ever since the first emergence of organisms, some form of organism agency must have been present, with organisms being "active drivers of evolution", as Noble (2021) rightly acknowledges.

While the neglect of the agency of organisms in general has been detrimental to our comprehension of living phenomena, the occasional neglect of human agency in biological theory has perhaps been particularly consequential. As Noble observes, "we are now in the middle of a further example of this process in what is called the anthropocene. We humans are now intentionally driving a major evolutionary transition". Few scholars now doubt that human agency is a driver of global environmental change. And yet, biological theories do not all acknowledge this evident fact. Noble (2021) is therefore quite right in noting that it "is ironic that the denial of our own intentionality may also become our own undoing" - given that biological theories have been central in shaping our worldview, which has in turn informed our actions in and with regard to the natural world.

Those who acknowledge that all organisms are endowed with semiotic agency, and thus the capacity to make choices while relating to signs, should also acknowledge the reality of what Jesper Hoffmeyer called 'semiotic causation'. Wherever there is an organism, there is semiotic agency at play, with the organism's interpretation of its circumstances becoming a causal force. As Hoffmeyer (2008: 149) wrote, semiotic causation concerns "the bringing about of changes [in the physical environment] under the guidance of interpretation".

Any organism can change its environment to some extent. But the changes that the human species has caused on a global scale are truly unprecedented, due to our increasing numbers, our ever-expanding economic activities, our improving technical skills, and thus, in sum, our increasing ability to shape environments so as to serve our own interests. Human agency truly has world-changing effects, and for current ecological circumstances, the 'Anthropocene' is a fitting designation. Scholars now discuss 
when the Anthropocene might have started, with some suggesting quite recent times, such as the post-war era, though time frames going back to the industrial revolution or even to the first emergence of extensive agriculture have also been proposed (different time frames are discussed in Steffen et al., 2011 and Crutzen \& Steffen, 2003). In a biosemiotic perspective, these alternative Anthropocene narratives can be reframed as supplementary histories about the increasingly influential semiotic causation of human agents.

Noble sees illusions in the Modern Synthesis, but also in nature. The organisms that are capable of conscious action, he writes, "must also be capable of intended or unintended illusions." As an example of how biosemiotics can contribute to understanding such phenomena, he mentions my treatment of wolves in interaction with potential prey (Tønnessen, 2010). By understanding the Umwelt of a wolf, he notes,

we may come to understand its possible use of illusory behavior in predator-prey interactions [...] Organisms capable of anticipatory behavior surely must use such tactics in successful hunting, just as conscious prey must do so to avoid them. I suspect that this must be what Tønnessen has in mind when he refers to "the naïvety of prey". They become less naïve precisely through developing anticipation of the diversionary signs from predators.

"The naïvety of prey" is an established expression in contemporary ethology, but in the main reconcilable with Noble's interpretation. Most ethologists would perhaps rather say that for instance moose - a common prey of wolves - become less naïve with regard to the danger posed by wolves simply by being exposed to the presence of wolves over time. And statistics drawn from measurements would serve to prove the point. But of course, the presence of wolves is mediated to the moose by way of signs howls, scents, predatory attacks, and so on. Were it not for these signs of wolves, the moose would not have any idea about there being wolves around.

\section{How to Make Umwelt Bubbles Burst}

Noble also refers to my analysis of Umwelt and language (Tønnessen, 2015b). Could it be that the ways in which language transforms the Umwelt is key to explaining the world-changing effects of human agency? A central point in this context is as Noble rightly remarks in my view that "language is not external to the Umwelt, but internal to it. Language changes the human Umwelt not by escaping or sidelining it, but by fundamentally transforming it" (Tønnessen, 2015b: 77). Noble says this

gets to the core of what I think happened in the development of the illusions of the Modern Synthesis between 1940 and the end of the last century. Language was crafted in creating a coherent model of how organisms work and how they depend on and interact with their environment. In a biosemiotic context we could call it the Umwelt, the mind-set on the nature of the environment-organism interaction, of the Modern Synthesis. 
Von Uexküll himself did not include any analysis of the role of language in his exposition of the semiotic formation of the human Umwelt. ${ }^{1}$ Nevertheless, this comes quite close to his characterizations of the Umwelten of different groups of human beings. "The Umwelt of the Modern Synthesis" is in this light the encultured and shared subjective world of believers in the theses of the Modern Synthesis. Such an Umwelt offers a worldview, an outlook on the natural world - and is deeply influenced by paradigmatic linguistic framing tools. "Language", as Heidegger (1971) would have it, "is the House of Being." So powerful is the human language that to human beings, non-linguistic reality is inferior in principle. We name things, and thereby the world (as we see it) comes into existence.

Von Uexküll at one point portrayed an Umwelt as a bubble. In A foray into the worlds of animals and humans (von Uexküll, 2010: 43), he writes about a stroll into nature.

We begin such a stroll on a sunny day before a flowering meadow in which insects buzz and butterflies flutter, and we make a bubble around each of the animals living in the meadow. The bubble represents each animal's environment [Umwelt] and contains all the features accessible to the subject. As soon as we enter into one such bubble, the previous surroundings of the subject are completely reconfigured. Many qualities of the colorful meadow vanish completely, others lose their coherence with one another, and new connections are created. A new world arises in each bubble.

The bubble metaphor gives the impression that animals are encapsulated into subjective worlds that are inaccessible to anyone else and separated from the surrounding natural world. But of course, von Uexküll realized that Umwelt research is possible - after all, he founded an Institute for Umwelt research. His bubble metaphor also extended to human beings, or groups of human beings - for instance, he stressed that different scientific specializations generate different expert Umwelten (von Uexküll, 2010: 133-135). In this context, different forms of scientific language obviously play a significant role in distinguishing one form of scientific specialization from another. And furthermore, paradigmatic linguistic framing tools, such as concepts and metaphors, can distinguish one approach to some subject matter from another. So why not talk about the Umwelt of the Modern Synthesis? Umwelt creatures endowed with this particular kind of Umwelt are prone to believe in a set of shared ideas, or illusions, as Noble succinctly describes. They do not acknowledge that organisms are agents endowed with semiotic agency and capable of using the powers of semiotic causation. Nor do they realize that they live in a bubble. If only they had read some biosemiotic theory, their Umwelt bubbles might have burst.

\footnotetext{
${ }^{1}$ I thank a peer-reviewer of this commentary for stressing this point. This is one reason for why von Uexküll's Umwelt theory needs to be further developed, particularly with regard to studies of the human Umwelt.
} 
Funding Open access funding provided by University Of Stavanger.

Open Access This article is licensed under a Creative Commons Attribution 4.0 International License, which permits use, sharing, adaptation, distribution and reproduction in any medium or format, as long as you give appropriate credit to the original author(s) and the source, provide a link to the Creative Commons licence, and indicate if changes were made. The images or other third party material in this article are included in the article's Creative Commons licence, unless indicated otherwise in a credit line to the material. If material is not included in the article's Creative Commons licence and your intended use is not permitted by statutory regulation or exceeds the permitted use, you will need to obtain permission directly from the copyright holder. To view a copy of this licence, visit http://creativecommons.org/licenses/by/4.0/.

\section{References}

Crutzen, P. J., \& Steffen, W. (2003). How long have we been in the Anthropocene era? An editorial comment. Climatic Change, 61, 251-257.

Heidegger, M. (1971). On the way to language. Harper \& Row.

Hoffmeyer, J. (2008). Semiotic scaffolding of living systems. In M. Barbieri (Ed.), Introduction to biosemiotics: The new biological synthesis (pp. 149-166). Springer.

Müller, G., \& Newman, S. A. (2003). Origination of organismal form: The forgotten cause in evolutionary theory. In G. Müller \& S. A. Newman (Eds.), Origination of organismal form (pp. 3-10). MIT Press.

Noble, D. (2015). Evolution beyond Neo-Darwinism: A new conceptual framework. The Journal of Experimental Biology, 218, 7-13.

Noble, D. (2021). The illusions of the modern synthesis. Biosemiotics. https://doi.org/10.1007/s12304-02109405-3.

Schlosser, M. (2019). Agency. The Stanford Encyclopedia of Philosophy (Winter 2019 Edition), Edward N. Zalta (ed.), URL $=<$ https://plato.stanford.edu/archives/win2019/entries/agency/ $>$.

Steffen, W., Grinevald, J., Crutzen, P., \& McNeill, J. (2011). The Anthropocene: Conceptual and historical perspectives. Philosophical Transactions of the Royal Society A: Mathematical, Physical and Engineering Sciences, 369(1938), 842-867.

Tønnessen, M. (2010). Wolf land. Biosemiotics, 3, 289-297.

Tønnessen, M. (2015a). The biosemiotic glossary project: Agent, agency. Biosemiotics 8(1), 125-143. With Appendix (Supplementary Material available online).

Tønnessen, M. (2015b). Umwelt and language. In E. Velmezova, K. Kull, \& S. J. Cowley (Eds.), Biosemiotic perspectives on language and linguistics (pp. 77-96). Springer.

von Uexküll, J. (2010). A foray into the worlds of animals and humans, with A theory of meaning. Trans. J. D. O'Neil. Minneapolis: The University of Minnesota Press.

Publisher's Note Springer Nature remains neutral with regard to jurisdictional claims in published maps and institutional affiliations. 